\title{
Why Capital's Effect Differs in Bank Size?
}

\author{
Ahmad Aziz Putra Pratama
}

\begin{abstract}
Banks are trusted institutions. Therefore, bank management must use all of its operational tools to maintain the trust of the community. A strategic tool in sustaining that trust is adequate capital. Until now, banking activities remain the same, but with a different system. Novelty this research is a different effect of bank capital on lending behavior in each bank size category. This study used the fixed effect model in the 2004-2018 period. This study proved that smaller bank tends to implement aggressive strategies with lower capital and higher loan proportion, while larger bank manages to implement a defensive strategy with high capital and higher loan proportion.

Keywords: Bank capital, Loan growth, Bank size
\end{abstract}

\section{INTRODUCTION}

The market concentration of the banking sector in Indonesia is highly concentrated. Banks, as intermediary institutions, play a strategic role in the economy. Financial institutions become a pillar in building an economic system. Banks are the place for various transactions, such as saving money, investing, payment transactions, money transfers or billing activities (Rose \& Hudgins, 2013). Banks, as financial institutions with dominant public funding sources, make banks as a highly regulated industry (Thalib, 2016). When a bank gives some credit, it will be exposed to risk (Satria \& Subegti, 2010). Banks in their operational activities have a lot to do with risk, so banks are institutions known as risk-taking entities (Junaidi, Sulastri, Isnurhadi, \& Adam, 2019; Raharjo, 2014).

The loan has an important role in the operations of a bank. Indonesia still uses the credit business sector as their primary source of income (Junaidi et al., 2019; Raharjo, 2014; Setiawan \& Pratama, 2019; Subandi \& Ghozali, 2013; Thalib, 2016). Bank capital adequacy is a significant concern because it will affect the operational activities of a bank (Berrospide \& Edge, 2010; Gambacorta \& Marques-Ibanes, 2011; Kim \& Sohn, 2017).

Capital is part of a very crucial thing. The size of capital indicates the level of the bank's ability to finance assets that contain risks (Gambacorta \& Mistrulli, 2004). Sufficient capital will be better able to cover the value of the declining assets resulting from bank losses (Kim \& Sohn, 2017).

Revised Manuscript Received on October 10, 2019.

* Correspondence Author

Ahmad Aziz Putra Pratama*, Master of Science in Management, Department of Management, Faculty of Economics and Business, Airlangga University, Surabaya, Indonesia. Email: Ahmad.aziz.putra-2018@feb.unair.ac.id

(C) The Authors. Published by Blue Eyes Intelligence Engineering and Sciences Publication (BEIESP). This is an open access article under the CC BY-NC-ND license (http://creativecommons.org/licenses/by-nc-nd/4.0/)

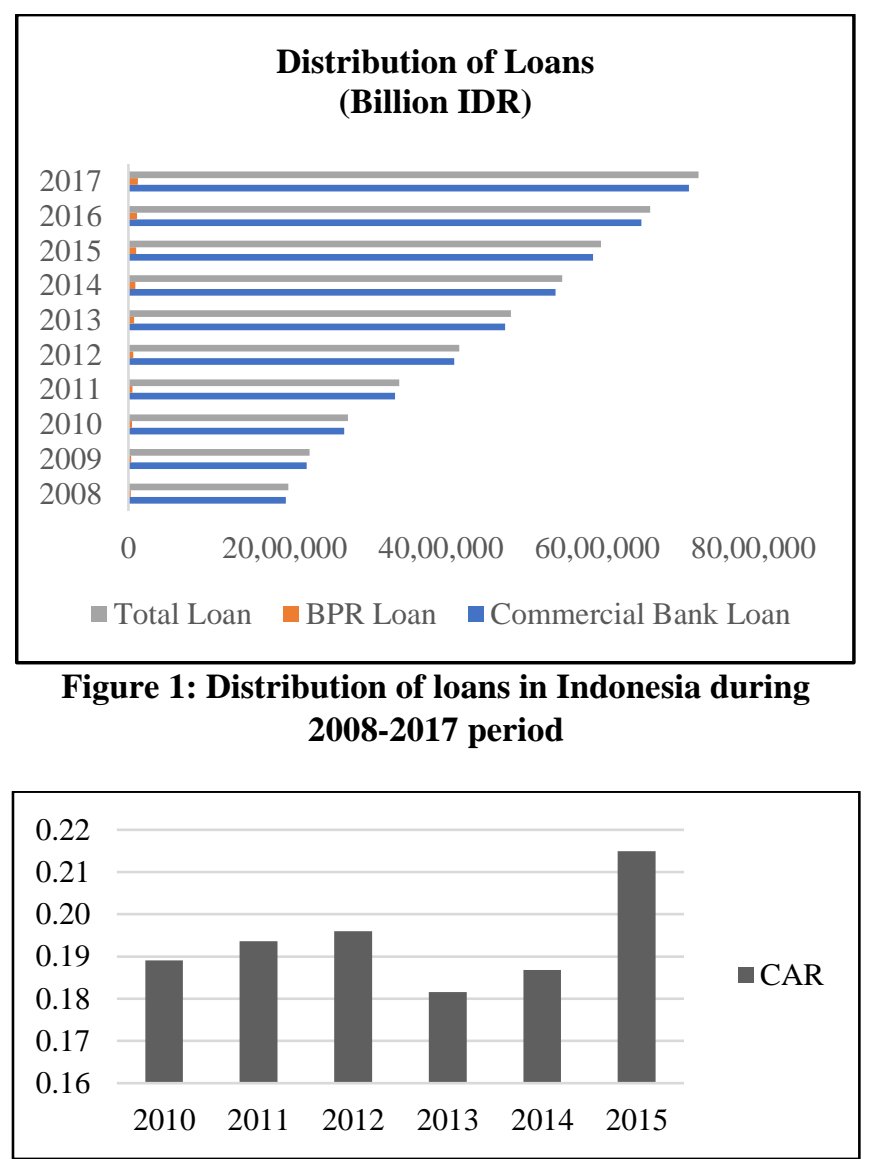

Figure 2: Average of CAR in the 2010-2015 period

Previous empirical study in Indonesia concerning determinant of bank loan (Satria \& Subegti, 2010), the effect of bank capital on performance (Raharjo, 2014; Subandi \& Ghozali, 2013; Thalib, 2016), bank risk (Kamaludin, Darmansyah, \& Usman, 2015) and sustainability growth rate (Junaidi et al., 2019). Earlier research only examined the effect of bank capital on credit growth but did not measure detail how it affected in each bank category based on its size.

The novelty of this research examines the effect of bank capital on loan growth based on its size. This study proved two strands of theories on the relationship between bank capital and liquidity creation, the "financial fragility-crowding out" and the "risk absorption" (Diamond \& Rajan, 2001; Gorton \& Winton, 2000). The difference with other studies is the sample based on firm size. This category consist of a small, medium, and large bank.

\section{METHODOLOGY}

Data used 40 banks listed on the Indonesia Stock Exchange (IDX) in the 2004-2018 period, with 589 observations.

Published By:

Blue Eyes Intelligence Engineering

\& Sciences Publication

DOI:10.35940/ijmh.B0394.104219

Journal Website: www.ijmh.org

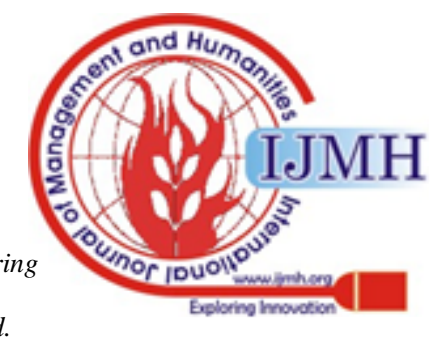


Purposive sampling criteria used in this study are banking public sector companies listed on the Indonesia Stock Exchange (IDX), based on conventional principles and not sharia, the financial statements provide complete data, presented in rupiah currency (IDR), and does not include banking companies with incomplete data.

This study used the Fixed Effect Model with STATA Statistics Data Analysis 14.2 Special Edition Version as a statistical tool. Kim \& Sohn (2017) recommend Fixed Effects Estimators as superior alternatives. Roodman (2009) also recommends Fixed Effects Estimators as excellent alternatives to dynamic system Generalized Method of Moment (GMM).

Table 1. Sample selection

\begin{tabular}{lc}
\hline Sample & Total \\
\hline Total Bank & 43 \\
Syariah bank (-) & 3 \\
\hline Total Sample & $\mathbf{4 0}$ \\
\hline All observation & 600 \\
Outlayer (-) & 11 \\
\hline Total observation & 589 \\
\hline
\end{tabular}

Note: Measurement through purposive sampling

This study divides the sample into three categories that consist of a small bank, medium bank, large bank. Large banks with total assets above the 80th percentile, medium banks are the 50th to 80th percentiles, and small banks include all other banks less than 50th percentile in each period. As a result, 88 observations are categorized as large banks, 184 observations are categorized as medium banks, and 317 observations are categorized as small banks.

This research used loan growth (LOAN) as a dependent variable and bank capital (CAR) as an independent variable. Controlling variables used in this research are asset quality (NPL), liquidity level (LIQ), bank's performance (ROA), gross domestic product (GDP), and market interest (MI).

Table 2. Operational definitions of variables

\begin{tabular}{ll}
\hline Variable & Measurement \\
\hline Loan growth & (Net loant - net loant-1)/net loant-1 \\
Bank capital & Bank capital/risk-weighted assets \\
Asset quality & Noncurrent loans/total loans \\
Liquidity level & Total liquid assets/total assets \\
Bank performance & Net income/total assets \\
Gross Domestic Product & The growth rate of real GDP \\
Market interest & Change in BI rate \\
\hline
\end{tabular}

The analysis model in this study was formulated as follows:

$$
\begin{aligned}
L_{O A N}= & \beta_{0}+\beta_{1} C A R_{i, t}+\beta_{2} N P L_{i, t}+\beta_{3} L I Q_{i, t}+\beta_{4} R O A_{i, t}+ \\
& \beta_{5} G D P_{i, t}+\beta_{6} M I_{i, t}+e_{i, t}
\end{aligned}
$$

\section{RESULTS}

Table 3. Panel data regression test results

\begin{tabular}{lr}
\hline Dependent variable: & \multicolumn{2}{c}{ LOAN (Loan growth) } \\
\cline { 2 - 2 } Bank category: & \multicolumn{2}{c}{ All Banks } \\
\cline { 2 - 2 } Analysis model: & \multicolumn{1}{c}{$\mathbf{( 1 )}$} \\
\hline & \multicolumn{2}{c}{$* * 3.311$} \\
Intercept & $\mathbf{( 0 . 0 2 5 )}$ \\
CAR (Bank capital) & $* * * 1.426$ \\
NPL (assets quality) & $\mathbf{( 0 . 0 0 1 )}$ \\
& $* * *-2.921$ \\
LIQ (Liquidity level) & $\mathbf{( 0 . 0 0 3 )}$ \\
& $* * \mathbf{0 . 2 2 1}$ \\
ROA (Bank performance) & $\mathbf{( 0 . 0 2 9 )}$ \\
GDP (Gross Domestic Product) & $* * * 2.639$ \\
MI (Market interest) & $\mathbf{( 0 . 0 0 0 )}$ \\
& $* * 1.175$ \\
& $\mathbf{( 0 . 0 3 2 )}$ \\
& $* * *-1.943$ \\
& $\mathbf{( 0 . 0 0 1 )}$
\end{tabular}

Fixed Effect $\quad$ Yes

Observations 589

R-Squared

0,2773

Source: STATA Statistics Data Analysis 14.2 Special Edition

Version

$* * * \quad$ Significant at $1 \%$ level
$* * \quad$ Significant at $5 \%$ level

* Significant at $10 \%$ level

Based on the results of the regression test, the bank capital proxied with CAR has a significant positive effect on loan growth in all bank samples, small banks, and medium banks. The results showed that the higher the bank's capital, the greater the amount of credit that can be distributed. These findings are in line with research conducted by Berrospide \& Edge (2010), Gambacorta \& Mistrulli (2004), Moussa \& Chedia (2016), Satria \& Subegti (2010), Setiawan \& Pratama (2019) which states that bank capital has a significant positive effect on bank lending.

Furthermore, bank capital also has a significant negative effect on loan growth in large banks. The results showed that the higher the bank's capital, the lesser the amount of credit that can be distributed. These findings are in line with research conducted by Diamond \& Rajan (2001), Gorton \& Winton (2000), Kim \& Sohn (2017) which states that bank capital has a significant negative effect on bank's loan.

Published By:

Blue Eyes Intelligence Engineering

\& Sciences Publication

(C) Copyright: All rights reserved. 
Table 4. Regression test results each bank's categories

\begin{tabular}{|c|c|c|c|}
\hline Dependent variable: & LOAN & (Loan gro & th) \\
\hline Bank category: & Small & Medium & Large \\
\hline Analysis model: & (1) & (2) & (3) \\
\hline Intercept & $\begin{array}{l}* 6.912 \\
(0.072)\end{array}$ & $\begin{array}{r}* * * 13.336 \\
(0.000)\end{array}$ & $\begin{array}{r}* * * 8.630 \\
(0.001)\end{array}$ \\
\hline CAR (Bank capital) & $\begin{array}{r}* * * 1.321 \\
(0.004)\end{array}$ & $\begin{array}{r}* * * 2.046 \\
(0.000)\end{array}$ & $\begin{array}{r}* *-1.138 \\
(0.018)\end{array}$ \\
\hline NPL (assets quality) & $\begin{array}{r}* *-2.712 \\
(0.041)\end{array}$ & $\begin{array}{r}* * *-8.374 \\
(0.003)\end{array}$ & $\begin{array}{r}* *_{-} 4.380 \\
(0.017)\end{array}$ \\
\hline LIQ (Liquidity level) & $\begin{array}{r}* * 0.169 \\
(0.031)\end{array}$ & $\begin{array}{l}* 0.211 \\
(0.077)\end{array}$ & $\begin{array}{r}* * 0.369 \\
(0.023)\end{array}$ \\
\hline ROA (Bank performance) & $\begin{array}{r}* * * 3.046 \\
(\mathbf{0 . 0 0 8 )}\end{array}$ & $\begin{array}{l}* 2.212 \\
(0.091)\end{array}$ & $\begin{array}{r}* * 3.836 \\
(0.016)\end{array}$ \\
\hline $\begin{array}{l}\text { GDP (Gross Domestic } \\
\text { Product) }\end{array}$ & $\begin{array}{r}* * 1.046 \\
(0.021)\end{array}$ & $\begin{array}{r}* 1.778 \\
(0.096)\end{array}$ & $\begin{array}{r}1.836 \\
(0.511)\end{array}$ \\
\hline MI (Market interest) & $\begin{array}{r}*_{-1.786} \\
(0.067)\end{array}$ & $\begin{array}{l}-1,201 \\
(0.112)\end{array}$ & $\begin{array}{r}*-1.836 \\
(0.053)\end{array}$ \\
\hline
\end{tabular}

\begin{tabular}{lrrr} 
Fixed Effect & Yes & Yes & Yes \\
Observations & 317 & 184 & 88 \\
R-Squared & 0,1813 & 0,1775 & 0,1976 \\
\hline
\end{tabular}

Source: STATA Statistics Data Analysis 14.2 Special Edition Version

*** Significant at $1 \%$ level

** Significant at $5 \%$ level

* Significant at $10 \%$ level

Banks in Indonesia are said to be healthy banks if they have successfully met Bank Indonesia's requirements. Capital adequacy ratio (CAR) can be used as a proxy of bank health. Based on Bank Indonesia regulations, banks must have a minimum CAR of $8 \%$ (POJK Number 11/POJK.03/2016). In Indonesia, capital adequacy ratio (CAR) in commercial banks 2010-2016 has a high average value of $19.37 \%$, well above $8 \%$ of the minimum amount required by Bank Indonesia. Bank capital adequacy is a significant concern because it will affect the operational activities of a bank (Berrospide \& Edge, 2010).

Capital adequacy is needed if, in the future, there is bad credit that will reduce the value of assets, then what is diminished on the liability side is bank capital itself (Setiawan \& Pratama, 2019). Bank capital will be eroded because it is not possible the bank will reduce third party funds (deposits). Banks must reduce their capital rather than their deposits (Rose \& Hudgins, 2013). If the bank reduces its deposits, the depositors will not trust the bank. From this point of view, banks are considered unable to manage their risks and depositors will suffer losses due to the declining value of their deposits. If the bank has a capital adequacy exceeding the requirements, the bank is considered to be better able to deal with credit risk.

Smaller banks have difficulty competing with large banks and will extend loans with a high risk of uncertainty. Small banks will increase their capital to absorb the credit risk, while large banks tend to have relatively little capital reserves compared to small banks. Large banks can enjoy economies of scale. Their client base is more likely to include stable, financially sound, and well-established businesses, and in general, they have more diversified portfolios across regions and products.

Smaller banks, when they have high capital, tend to implement aggressive strategies in lending to enlarge their business ventures and get high profits, strengthen the CAR value to absorb risk from increasing the amount of loan. In contrast, large banks tend to be more defensive because of circulating loans is already too much. A large bank has a diversified portfolio and a better variability source of income and lowering dependency on lending business. If the bank increases the amount of credit extended, it will increase the risk borne by the bank. Large banks category will focus more on the owned capital structure rather than increasing the amount of credit channeled.

Assets quality variable, which is proxy by NPL, has a significant negative effect on lending growth in all bank samples. Asset quality reflects the ability of assets owned by banks in providing credit (Rose \& Hudgins, 2013). Rabab'ah (2015) indicated that the rise in the proportion of the non-performing debt leads to a decline in the strength of the banking sector and the volume of the credit granted. The higher the level of NPL, the worse portfolio quality is. Banks reduce lending by more substantial degrees as loan quality worsens (Kim \& Sohn, 2017). This result showed that the higher the nonperforming loan, the smaller of loan's growth. Bank liquidity level has a positive effect on loan growth in all bank samples. The liquidity level depicts the bank's ability to absorb liquidity shocks. In theory, the higher liquidity ratio indicates that the bank is in a better position to meet its stochastic withdrawals. More liquid banks can provide more lending by drawing on their stock of liquid assets (Moussa \& Chedia, 2016). Bank performance variables proxy by ROA has a significant positive effect on the loan's growth in all bank samples. Banks with high profitability are likely to have strong balance sheets because profitability is related to the quality and quantity of capital ratios. Thus, a positive relationship between profitability and bank lending (Moussa \& Chedia, 2016). The growth rate of real GDP is positive because of the inherent procyclicality of bank lending and increased loan demands. Alternatively, the effect of changes in the interest rate on bank lending to be negative because increases in market rates decrease loan demands.

\section{CONCLUSION}

Several areas in banking have generated much debate and uncertainty with the rules of bank capital. This study proved two strands of theories on the relationship between bank capital and liquidity creation, the "financial fragility-crowding out" and the "risk absorption" theories.

Published By:

Blue Eyes Intelligence Engineering

\& Sciences Publication

DOI:10.35940/ijmh.B0394.104219

Journal Website: www.ijmh.org 
The "financial fragility-crowding out" hypothesis predicts that the effect of bank capital on lending is negative because, unlike depositors, capital investors who cannot run on the bank are reluctant to provide loans. Thus, banks with a higher capital ratio might supply fewer loans by crowding out deposits.

Conversely, the effect of bank capital on lending is positive under the "risk absorption" theory because bank capital enhances the bank's risk-bearing capacity. Bank management needs to pay attention to manage capital for measuring the ability of banks to provide loans. Banks that want to extend their credit need to pay attention to these capital variables. With considering this condition, banks have greater ability to extend their loans. By analyzing capital adequacy properly, banks can manage their risk very well. Investors can use capital reference in assessing the bank's health.

\section{REFERENCES}

1. Berrospide, J. M., \& Edge, R. M. (2010). The effects of bank capital on lending: What do we know, and what does it mean ? Finance and Economics Discussion Series, $1-48$.

2. Diamond, D. W., \& Rajan, R. G. (2001). Liquidity risk, liquidity creation, and financial fragility: A theory of banking. Journal of Political Economy, 109(2) 287-327. https://doi.org/10.1086/319552

3. Gambacorta, L., \& Marques-Ibanes, D. (2011). The bank lending channel: Lessons from crisis. Economic Policy, (1), 135-182.

4. Gambacorta, L., \& Mistrulli, P. E. (2004). Does bank capital affect lending behavior? Journal of Financial Intermediation, 13(4), 436-457. https://doi.org/10.1016/j.jfi.2004.06.001

5. Gorton, G., \& Winton, A. (2000). Liquidity provision, bank capital, and the macroeconomy. In Journal of Money, Credit and Banking (Vol. 49). https://doi.org/10.1111/jmcb.12367

6. Junaidi, S., Sulastri, S., Isnurhadi, I., \& Adam, M. (2019). Liquidity, asset quality, and efficiency to sustainable growth rate for banking at Indonesia Stock Exchange. Jurnal Keuangan Dan Perbankan, 23(2), 308-319. https://doi.org/10.26905/jkdp.v23i2.2699

7. Kamaludin, Darmansyah, \& Usman, B. (2015). Determinan non performing loan (NPL) pada industri perbankan (Bukti empiris perusahaan Go Publik di Bursa Efek Indonesia). Jurnal Aplikasi Manajemen, 13(4), 547-556.

8. Kim, D., \& Sohn, W. (2017). The effect of bank capital on lending: Does liquidity matter? Journal of Banking and Finance, 77, 95-107. https://doi.org/10.1016/j.jbankfin.2017.01.011

9. Moussa, M. A. Ben, \& Chedia, H. (2016). Determinants of bank lending: Case of Tunisia. International Journal of Finance and Accounting, 5(1), 27-36. https://doi.org/10.5923/j.ijfa.20160501.04

10. POJK. Peraturan Otoritas Jasa Keuangan Nomor 11/POJK.03/2016 Tentang Kewajiban Penyediaan Modal Minimum Bank Umum. , (2016).

11. Rabab'ah, M. (2015). Factors affecting the bank credit: An empirical study on the Jordanian commercial banks. International Journal of Economics and Finance, 7(5), 166-178. https://doi.org/10.5539/ijef.v7n5p166

12. Raharjo, P. G. (2014). Faktor determinan marjin bunga bersih bank pembangunan daerah Di Indonesia: Suatu studi data panel. Jurnal Keuangan Dan Perbankan, 18(1), 105-119.

13. Roodman, D. (2009). How to do xtabond2: An introduction to difference and system GMM in Stata. Stata Journal, 9(1), 86-136.

14. Rose, P. S., \& Hudgins, S. C. (2013). Bank management \& financial services (9th ed). New York: McGraw-Hill Education.

15. Satria, D., \& Subegti, R. B. (2010). Determinasi penyaluran kredit bank umum di Indonesia periode 2006-2009. 14(3), 415-424.

16. Setiawan, R., \& Pratama, A. A. P. (2019). Modal, tingkat likuiditas bank, NPI dan pertumbuhan kredit perbankan Indonesia. Matrik: Jurnal Manajemen, Strategi Bisnis Dan Kewirausahaan, 13(1), 96-107. https://doi.org/https://doi.org/10.24843/MATRIK:JMBK.2019.v13.i01.p10

17. Subandi, \& Ghozali, I. (2013). Determinan efisiensi dan dampaknya terhadap kinerja profitabilitas industri perbankan di Indonesia. Jurnal Keuangan Dan Perbankan, 17(1), 123-135.

18. Thalib, D. (2016). Intermediasi, struktur modal, efisiensi, permodalan dan risiko terhadap profitabilitas bank. Jurnal Keuangan Dan Perbankan, 20(1), 116-126. https://doi.org/10.26905/jkdp.v20i1.155

\section{AUTHORS PROFILE}

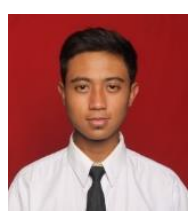

Ahmad Aziz Putra Pratama, Undergraduate of Maste of Science in Management, Department of Management, Faculty of Economics and Business, Airlangga University, Surabaya, Indonesia. Aziz is an enthusiastic trader and researcher. In his academic exellence has published 2 national and 2 international journal. He also participated in 2 national seminars and conferences and guide 3 management project. 